\title{
An Ecocritical Approach to Identity Representation in Patrick Chamoiseau's Chronique des sept misères
}

\author{
Bethany Mason \\ University of Birmingham
}

"II faut accompagner l'énergie du monde frère, pas la soumettre" (Chronique 140). This message, presented by Patrick Chamoiseau through the minor, but important, character of the Rasta in his first novel Chronique des sept misères ${ }^{1}$ epitomises the struggle between European power and the Other ${ }^{2}$ during colonisation, and shows that nature and humans have been affected by the same colonial force. This paper demonstrates how the conquering of the land can be inextricably linked to the conquering of identity by European colonialism in the Americas, and to the subsequent postcolonial exploitation of the French Caribbean islands of Martinique and Guadeloupe by metropolitan France. Applying ecocriticism to postcolonialism shows the "masters and possessors of nature" (Descartes 78) to be the same masters and possessors of people. Lizabeth Paravisini-Gebert argues that "environmental problems are a manifestation of other, larger problems endemic to culture, society, and economic structures in colonized societies struggling to continue to exist in a globalized world" (Extinctions' 354). Paravisini-Gebert seems to imply that to solve environmental problems such as climate change, it is necessary to explore the problems that are ingrained in certain cultural, societal and economic structures such as a nature/culture dualism and the Hegelian master/slave dialectic which can be applied to nature. The image of the Other which has been created by and in opposition to the coloniser can be applied to both humans and nature. Richard Watts (2008) points out how "[in] the epistemology constructed by the colonizer, the colonized and nature occupy the same space of difference, which is external to the colonizer and can be exploited for economic benefit" (255). Watts posits that as an 'Other', nature has often been presented in opposition to humanity and as a construction against the coloniser's image of the self. He argues that a decentring of humans from postcolonial analysis is essential to prevent nature becoming analogous to a postcolonial Other. Through the lens of postcolonial ecocriticism, this paper demonstrates how Chamoiseau's Chronique shows the relationship between identity and the environment in a way which moves away from anthropocentrism, the antithesis of which Val Plumwood has described as "countering and

\footnotetext{
${ }^{1}$ Hereafter referenced as Chronique.

2 The word 'Other' will be used throughout to mean the Other constructed by colonialism. Chamoiseau himself often reappropriates and reifies this word using capitalisation as can be seen in his recent manifesto Frères migrants: "Les poètes déclarent que le racisme, la xénophobie, l'indifférence à l'Autre [...] est un acte criminel”" (Frères migrants).
} 
subverting the human/nature dualism that is part of human-centeredness and resituating humans in ecological terms" (124).

Whereas the primarily Anglophone field of ecocriticism has been developing rapidly since the $1990 \mathrm{~s}$, French ecocriticism ${ }^{3}$ has been developing at a slower rate (Finch-Race, Posthumus), and it is only relatively recently that a postcolonial ecocriticism considering the Francophone Caribbean has emerged. In 1975, André Gorz argued that "la lutte écologique n'est pas une fin en soi, c'est une étape" [original emphasis] (9), and suggests that an economic revolution would be necessary to establish "un nouveau rapport des hommes à la collectivité, à leur environnement et à la nature" (9). Here, Gorz links the environment to a collective identity through his argument that economic change is necessary for a better relationship between the two. The mobilisation of a collectivité emerges as a key notion in Chamoiseau's work, such as Chronique, as a way of pushing colonial boundaries that enforce dualism. In 1990, Michel Serres aimed to explore an ecocriticism which moves beyond nature/culture dualism in Le Contrat Naturel. He argued that nature does not need to be given human characteristics in order to form a "contract" with it as "[e]n fait la Terre nous parle en termes de forces, de liens et d'interactions, et cela suffit à faire un contrat" (69). Despite this assertion by Serres, Chamoiseau's personification of the environment serves as a powerful link between nature and humanity as it presents them in the same literary space.

As Watts has argued, a lack of ecocritical analysis in the field of postcolonial studies reinforces colonial domination of nature (253), highlighting the importance of combining the two fields. Bishop and Payne argue that environmental problems are "the ultimate Pan-Caribbean issue" (1536), underscoring the importance of applying an ecocritical postcolonial approach to the Caribbean in a way which works across linguistic and geographical borders. In 2005, Elizabeth DeLoughrey, Renée Gosson and George Handley discussed the Caribbean region as a construction to argue that it is the most radically altered environment in the world. They point out how the arrival of Europeans and their belief that the land was "new" led to the development of a Caribbean plantocracy which "confused plant diversity with an extraordinary yield for food" (6). This created a focus on both humanity and the land as commodities to satisfy those in power, thus the development of a plantocracy and the use of slavery became a way to master both humanity and nature at once through the production of food. This creation of the dependency of slaves on slave owners based on food production has been perpetuated through the construction of a dependency of Martinique and Guadeloupe on France for the importation of food. Paravisini-Gebert points out that approximately only $2 \%$ of food consumed

${ }^{3}$ Which will be explored in this work as both ecocriticism applied to the Francophone Caribbean and ecocritical engagements in the French language. 
in Martinique is currently produced there, rendering food security a major issue and highlighting the urgency of a discussion of the continued domination of the islands by French powers, especially when combined with the betonization (cementification) of the land, the pollution of land and water by pesticides, and a destruction of wildlife ('Food, Biodiversity, Extinctions' 23). Furthermore, " $[t]$ he neo-liberal phase of multi-national global capitalism has served to further exacerbate economic dispossession in the Antilles" and has damaged the relationship between the Antillean land and the production and consumption of food (Hardwick, 'Towards Biopolitical Ecocriticism' 6). This highlights the political and cultural urgency of a debate concerning the metropolitan domination of the French Caribbean environment and the continuation of an enforced estrangement between Antilleans and the land.

Despite Chamoiseau's active involvement in ecological issue ${ }^{4}$ and numerous ecological references in many of his novels and articles, his work has received a surprising lack of ecocritical attention, particularly in relation to French Caribbean identity. This paper addresses this gap with a close textual analysis of Chronique which, apart from Renée Gosson's article 'For What the Land Tells' and Lorna Milne's chapter 'Echanges et ouvertures: le marché', has received very little ecocritical attention despite its often overt demonstrations of the connections between nature and humanity. Chamoiseau is also co-author of Eloge de la créolité, which aims to highlight the need for recognition of Creole identity, which they argue comes from an in-between position (Bernabé et al. 891). Significantly, the créolistes use metaphors of food and the environment to highlight the mixing of cultures that is necessary for a Creole identity: "Creoleness is our primitive soup and our continuation, our primeval chaos and our mangrove swamp of virtualities" (892). The notion of the rhizome, as expounded by Gilles Deleuze and Félix Guattari and explored by Edouard Glissant (Poétique de la Relation) can be seen here as the créolistes use the mangrove, with its tangled roots, as a metaphor for the crossing over of multiple identities. This notion can be seen in the work of Chamoiseau through the intertwining of Creole and French language and culture, and he extends it to include nature as a conscious being through personification and magical realism. The idea that all beings have consciousness is key to many of Chamoiseau's novels as he has recently explained: “C'est une esthétique, c'est une poétique, mais c'est aussi une éthique qui constitue le soubassement de mes livres..." (Chamoiseau, De Vriese 128). A close textual analysis of Chamoiseau's Chronique reveals how the representation of this consciousness, which works to unite humanity and nature, is demonstrated by the author through both the relationships between characters and the Earth and the personification of the natural environment. This work will demonstrate how Chamoiseau

\footnotetext{
4 Chamoiseau was vice president of MODEMAS (Mouvement des démocrates et écologistes pour une Martinique souveraine) in the 1990s, and he is active on social media promoting ecological causes - see https://twitter.com/pchamoiseau?lang=en.
} 
uses the personification of the environment to resist the humanity/nature dualism at the centre of an estrangement between Antilleans and the land. It will then consider (post)colonial intervention and exploitation of both humanity and nature, and how this relates to current food production problems in the region, before exploring the roles that capitalism and consumerism have played in the perpetuation of this dualism.

\section{Personification of the Environment}

In Chronique, Chamoiseau uses the personification of the land to resist a nature/culture dualism, and the French metropolitan domination of the Martinican land, by confusing the distinctions between the two. One way that Chamoiseau demonstrates this is through the character of Afoukal, who serves as a symbol for the resistance of an estrangement between Antilleans and the environment. Linda Coverdale points out in her afterword of the English translation that the role of Afoukal is the "master storyteller, [who] must literally raise a concealed world to the level of consciousness, for who else will break the silence and tell the people of Martinique who they are?"'[original emphasis] (Chamoiseau, Chronicle of the Seven Sorrows 214). Afoukal himself is concealed in the land after being murdered by his master who upon hearing of the abolition of slavery buries all that is of worth to him. Lorna Milne argues that Pipi's illusion of Afoukal's jar of gold as a solution to the problems faced by the market "est bien sûr inappropriée, car le déclin du marché représente un drame non seulement économique mais aussi culturel" (80). However, the reader later discovers that there is no gold buried there and through the zombie slave, Chamoiseau reminds the reader that "toutes les richesses ne sont pas d'or : il y a le souvenir..." (Chronique 238), and thus I would argue that this search for gold is a search for a forgotten culture, or identity, rather than being representative of a solution to economic decline. Here, the forgotten culture is a creolised one incorporating both an African identity and an Antillean identity, and this search is representative of a forged connection which developed as plantation slaves were made to work the unfamiliar land. Afoukal is therefore a symbol of the bridge between the Antillean environment and the memory of slavery, encapsulating the link between nature and humanity. Furthermore, Chamoiseau seems to be suggesting that Antillean history needs to be awakened and the gold (memory) released in order for a Creole identity to develop. Glissant points to the land as a storyteller and thus as an important character in re-appropriation of history: “The storyteller's cry comes from the rock itself. He is grounded in the depths of the land; therein lies his power" (Caribbean Discourse 237). The character of Afoukal can therefore be seen as a personification of the land as he tells the history of slavery on the island from underneath the soil, showing how this human history is inextricably linked to nature. Moreover, Gosson has argued that any act against the land is seen as "an act of violence against the collective memory of the past" ('For What the Land Tells' 219), therefore as an act 
against a collective Caribbean identity. Thus, Pipi's deterioration following his attempt to take gold from Afoukal as the personification of the land can be read as Chamoiseau's argument that nature and humans need to work together to heal a collective memory, but that consumerism, which has followed colonialism, is reinforcing the boundaries between nature and humanity. There are examples of humanity working with nature to remember the devastating colonial history of slavery in the Caribbean. DeLoughrey and Handley argue that "[s]ince it is the nature, so to speak, of colonial powers to suppress the history of their own violence, the land and even the ocean become all the more crucial as recuperative sites of postcolonial historiography" (Postcolonial Ecologies 8). Projects such as the Slave Wrecks Project ${ }^{5}$ work to uncover the history of slavery from within the natural environment, and historical monuments that stand out in the landscape of Guadeloupe and Martinique ${ }^{6}$ can work as powerful reminders of the lives involved in the slave trade where a written history has worked to forget them, and they provide examples of the breaking down of boundaries between humanity and nature.

The way in which Afoukal speaks to the reader is through Pipi and "Les dix-buit paroles rêvées qu'Afoukal lui offrit" (Chronique 151). These "paroles rêvées", or Dream-Words, allow Pipi to "remont[er] sa proper mémoire" (151) to rediscover the history of slavery in the French Caribbean through the personification of the land. The paroles revées are presented as an indented, numbered list which is set apart from the main narrative through the use of parentheses, much like many characters' individual stories. The parentheses suggest both that the reader should pay close attention to this piece of explanatory text and that the narrative would work without this information. This shows Chamoiseau's criticism of the way in which these stories are omitted from European History (which is taught in schools in the French Caribbean) whilst also mimicking the enumerated and methodical way in which facts are often presented in European textbooks. This is comparable to the way in which he criticises a eurocentric version of the History of the Americas in his novel Chemin-d'école: "les Européens étaient les fondateurs de l'Histoire [. . . Et, avec l'arrivée des colons, la lumière fut. La Civilisation. L'Histoire. L'humanisation du grouillement de la Terre" (170-171). In this novel, the order of learning history from European books is broken up by and contrasted to the magical realism of Gros-Lombric's Creole stories and the protagonist's suggestion that they can "strike down" the teacher using magic, much like Afoukal relates in his stories of the papa-fenilles who poison the master during slavery (Chronique 161-162). It is important to note that Chamoiseau is showing here how nature can be used to resist colonial and postcolonial domination through the use of the name papa-fenilles for this

\footnotetext{
${ }^{5}$ For more information, see https://www.slavewrecksproject.org/.

${ }^{6}$ Such as Memorial ACTe and Fort Delgrès in Guadeloupe, and L'Anse Caffard and La Savane des Esclaves in Martinique.

${ }^{7}$ The word used in French is amarrer.
} 
character. Furthermore, through this personification of nature, Chamoiseau shows a resistance to the nature/humanity dualism which has been projected onto the region through colonialism.

Afoukal's first parole rêvée points to the initial crossing of the Atlantic made by slaves: "les mares mauvaises rapportaient ces milliers de méduses qui devaient brutalement réinventer la vie, sans une eau si ce n'est souvenir" (151). Here, the "evil tides" represent French colonialism and the jellyfish are the thousands of slaves left without an identity. The comparison of slaves to jellyfish here could be suggestive of the power Chamoiseau aims to reappropriate to slaves as they can sting if they feel threatened. This imagery of waves created by Chamoiseau is like that seen in Glissant's Caribbean Discourse, as well as in the work of Derek Walcott, ${ }^{8}$ and, as mentioned by J. Michael Dash, in imagery by Benítez-Rojo, all connecting identity to the sea. Metaphors linking the sea and identity can be seen in other parts of the novel. Afoukal describes the way in which slaves in the canefields were metaphorically drowning: "Pense à [...] la mort de chaque heure dans l'acceptation comme fatale de cette lente noyade" (Chronique 153). Describing the work carried out as drowning links back to the "les mares mauvaises" which represented French colonialism, and it can be argued that this metaphor suggests that French colonialism removed the identities of those they brought to the Caribbean islands and slowly created new ones based on power and hierarchy. Representation of Pipi's identity can also be seen to be influenced by the imagery of the sea, showing Chamoiseau's linking of humanity and nature. Pipi's identity is represented again, through the use of pathetic fallacy, as an evil place following the discovery of his father's identity: "Pipi, éjecté de l'enfance, entamait sa dérade" (53), ${ }^{10}$ and the characters could see "Pipi s'enfermait chaque jour un peu plus dans une sorte de tournis fixe que l'éloignait de nous, de la vie, et, impossible véridique, de lui-même (ô misère sous-marine)" (53).

Afoukal informs Pipi, and the reader, about the back-breaking work carried out in the fields during slavery through the personification of the earth: "Et le champ nous avalait jusqu'à l'anus nocturne" (Chronique 153). Here there is a reference to eating which is linked to suffering through the vulgar imagery of the land defecating being represented as the relief that came for slaves from the end of a working day. In the same Dream-Word, he also describes the working of the soil as combing out "de longs cheveux brûlants" (152). In the sixth Dream-Word, Afoukal describes the relationship between the slaves and the earth: "La terre était belle et nous touchait l'épaule. Certains pouvaient lui parler" (155). This personification is

\footnotetext{
${ }^{8}$ For example his poem 'The Sea is History', in which the transatlantic slave trade and emancipation are referenced.

${ }^{9}$ For example in The Repeating Island.

${ }^{10}$ Translated into English in Chronicle of the Seven Sorrows as "Pipi, alas, driven by storm from the shelter of childhood, began heading out to sea" (Chamoiseau 34).
} 
in contrast to the estranged representation of the earth given by papa-feuilles whilst he and Pipi are discussing their identities as he remarks: "Je sais que la terre d'ici nous est étrangère, elle me le dit tout le temps"' (185). This can be compared to a lack of intergenerational communication in the French Caribbean which, it can be argued, attributes to the 'forgetting of history' which Chamoiseau is trying to prevent through his literature. He then goes on to ask, "sais-tu d'où nous venons?" and Pipi replies, "D'Afrique..." (185). The break in speech and ellipsis signify a dramatic scene of recognition - a scene in postcolonial literature in which characters learn about their identity and which "[emphasizes] the importance of open discussion about the colonial past" (Hardwick Childhood, Autobiography 120), as well as a gap in a collective historical memory. The silence signified by the ellipsis suggests that the scene of recognition takes place outside of the novel and could be suggestive of Pipi's need to search inside himself for his ancestral identity. Moreover, despite papa-fexilles' insistence that the land is a stranger to him, his close relationship to the environment is clear in his identity which is even suggested by his name. This merging of the land and identity can be seen to transfer to Pipi through this exchange of words, silences and the examination of Pipi's skin as papa-fenilles tells him: “Tu es paré”" (185), and Pipi connection to the land intensifies.

This search for identity through a close relationship to the environment is highlighted by both papa-fenilles and Afoukal. Papa-fenilles describes himself as "“un ti-compère des feuilles, un ami des arbres..."” (Chronique 184) and he heals Pipi "comme une plante" following his deterioration in the field in search for Afoukal's gold (182-183). The potential healing power of the land is shown here as an alternative system of knowledge to western scientific medicine and thus a Creole identity is juxtaposed with a European identity through the environment once more. The healing power of plants has also been explored in Joseph Zobel's novel La rue Cases-Nègres, in which the grandmother, M'man Tine, uses roots and leaves to heal protagonist José and which is rich in descriptions of the environment, for example the comparison of M'man Tine's hands to that of the cracked earth due to her back-breaking work in the field: "[s]es mains noires [. . .] chaque craquelure incrustée d'une boue indélébile" (Zobel 310). However, it could be argued that in Chronique both papa-fenilles and Afoukal seem to represent the Europeanised vision of the tree as lineage, analysed by Heidi Bojsen as the antithesis of Glissant's Relation. This can be seen in the questioning of the papa-fenilles: “'Les racines sortent de la graine? Mais la question est: d'où vient la graine, et la graine de la graine ?"' (Chronique 185). The djobbers (the wheelbarrowing odd-job men of the market) are also compared to a tree in the novel - a mango tree - from which Pipi has grown and which Pipi represents (17). After Pipi learns of Afoukal, he becomes "plus bizarre qu'un mangot ${ }^{11}$ hors saison" and "[i]l n'avait plus le goût des djobs" (150). It is

${ }^{11}$ Name for a small mango in Martinique. 
interesting that the tree chosen to represent these characters is a mango tree as the mango is native to India and had been brought to the Americas during colonisation, again showing the varied influences on the Caribbean environment and identity. Although the mango, as representative of indentured labourers from India, is not native to the Antillean land it is central to a Caribbean identity. This is comparable to the centrality of an African identity to the Caribbean despite the links forged between slaves brought over from Africa and the Antillean land, something which can be seen in Pipi's search for identity.

In this search for identity, papa-fenilles engages with the Négritude movement by asking about his links to Africa. This is also explored by Afoukal, who seems to point out the limitations of Aimé Césaire's Retour an pays natal which alludes to a return to Africa. While Afoukal points out Pipi's roots to him, leading Pipi to repeat this to the market sellers: "Kongos, Bambaras, Mandingues, tous fils d'Afrique..."' (Chronique 169), Afoukal also argues that "'Y'a plus d'Afrique fout! Où c'est d'abord, l'Afrique? Où sont les sentiers, les tracées du retour? Y'a des souvenirs du chemin sur les vagues?"' (213). Afoukal also highlights the essence of identity questions at the heart of the Créolité movement: "'Qu'allez-vous faire de toutes ces races qui vous habitent, de ces deux langues ${ }^{12}$ qui vous écartèlent, de ce lot de sangs qui vous travaille?"' (213). The créolistes suggest a solution to having "two tongues": "We must accept this perpetual bilingualism and abandon the old attitude we had towards it. Out of this compost we must grow our speech" (Bernabé et al. 899), thus linking language to nature by comparing the growing of a new language identity based on many others to the growing of new life.

\section{2. (Post)colonial Intervention and Exploitation}

The personification of the earth and the environment can also be seen in Pipi's garden, which represents the changing of food production methods following the departmentalisation of Martinique (which became a DOM) ${ }^{13}$ in 1946 under the leadership of député Césaire. Through Pipi's garden, the close relationship between slaves, their descendants, and the earth is contrasted to the disengagement between the colonial urbanisation and industrialisation of the environment. It seems that for Chamoiseau, food is inextricably linked to a Creole identity as a method of resistance to European hegemony, something that can be seen in the development of Pipi's garden. Pipi goes to the "Rastas" in the woods to ask them for the "secrets que la terre leur confiait" (Chronique 195). The response he receives, that the world should not be conquered, epitomises the message of the entire novel, and this echoes Bojsen's analysis that "[i]n Chamoiseau's texts there is no

12 Translated into English in Chronicle of the Seven Sorrows as "two tongues" (Chamoiseau 153).

${ }^{13}$ Martinique became a "collectivité territoriale unique" in December 2015. 
question of "mastering the land"; rather, one lives with it" (220). Not only does this highlight the message Chamoiseau gives the reader regarding the way in which the environment is treated, but it also highlights a strong anticolonialist position. Therefore, this shows how he uses the treatment of the environment as a metaphor for the conquering of the Caribbean by the French and the subsequent identity questions that have arisen as a result.

Moreover, through providing competition to supermarkets by growing a successful garden which allows market vendors to lower their prices, Pipi showed "que l'indépendance était viable" (Chronique 200). This shows how food production is central to the question of independence as well as highlighting Chamoiseau's pro-independence political position, which has been indicated in Chamoiseau's contributions to political essays: Éloge de la Créolité, Manifeste pour refonder les DOM, and Manifeste pour les 'produits' de baute nécessité. The narrator points out that through his garden, Pipi had again become "la référence majeure des organisations anticolonialistes du pays" (Chronique 200), highlighting the links between food production, the environment, and identity. Furthermore, a criticism of globalisation and the increasing replacement of markets for supermarkets, as well as an echo of the suggestions contained in the above essays that work should be for selffulfilment, can be seen when Marguerite tells Pipi that "Pièce nègre ne travaillerait sur cette terre si toutes les ignames couraient-venir tout les temps..." (197). Marguerite's comment is a critique by the author regarding consumerism and the role of supermarkets in the relationship between Antilleans and food. In analysing the role of the 2009 strikes on the islands, Hardwick points out how "[f]rom their creation the early colonies existed in order to benefit the mère-patrie", thus the islands had to produce food that was not available in metropolitan France, which led to France's "monopoly rights over all colonial production" (Hardwick, 'Depicting Social Dispossession' 290). This development of the islands of Martinique and Guadeloupe as "transfer economies or consumer colonies" (Aldrich and Connell 7) has positioned these islands as a place of production to benefit the French metropole, demonstrating how humanity and nature continue to be mastered by the same (post)colonial force in the French Caribbean.

Highlighting the disconnect between the Antillean environment and colonialism, Pipi's garden becomes subjected to 'modern methods' of gardening. Descartes argued that it was necessary for man to become master and possessor of nature in order to enjoy "without any effort, the fruits of the earth and all its commodities" (78), and this approach can be seen here in the replacing of a unity with nature with a dualistic approach focused on extraction. Showing a link between linguistic identity and this approach, Pipi learns French so that he can 'rationaliser' in collaboration with the scientists. However, he "se laissa influencer par les hommes de science", who use pesticides, and eventually "quelque chose se dérégla dans le jardin" (Chronique 203), ending in the total destruction of Pipi's garden. The mention 
of pesticides here by Chamoiseau is significant as he seems to be prefiguring a scandal which was to emerge in the French Caribbean, as well as the métropole, years later. The kepone (chlordécone) scandal emerged in $2007,{ }^{14}$ and has "resulted in the long-term pollution of Caribbean DOM soils" due to its continued use there, despite being banned years earlier in metropolitan France (Hardwick 'Depicting Social Dispossession' 301). After the findings of a 2007 report into their continued use were released, residents in Martinique and Guadeloupe were discouraged by the French Minister of Health from consuming produce from their own vegetable gardens (Torny 14-15), highlighting once more the dependency of the islands on imported produce. The use of pesticides in the novel is symbolic as it destroys not only the physical land in Pipi's garden but also the possibility of agricultural independence which has resonance in the possibilities of brief liberation for slaves who were allowed to grow and sell produce during slavery on the islands. ${ }^{15}$ Combined with the kepone scandal which has rendered soil unusable for the growing of produce, the effects of which are predicted to last a century, this demonstrates another form of domination of the land and food production by the métropole.

The garden shows Chamoiseau's criticism of intervention on both an environmental and scientific level, but it can also be read as a criticism of the continued destructive imperialism and domination of France, and French, on Martinique and Guadeloupe and on their respective identities. Through Pipi, Chamoiseau links the creativity of gardening and producing food to the poetics of his own writing and his defiance of the French language through his use of Creole and exploitation of the metonymic gap - something which is hidden to the colonial power much as Pipi's garden contains inaccessible 'secrets'. Chamoiseau himself points out how "П] livres ne sont jamais seulement des jardins..." (Chamoiseau and De Vriese 131). He explains that there used to be "une intuition écologique formidable" (Chamoiseau and De Vriese 131), shown here through Pipi, and that gardens allowed Antillean slaves to survive, but that now this balance has been disrupted by scientific intervention and urban spaces, much like how Pipi's garden has. This disruption of the environment is representative of the ways in which science, urbanisation and imperialism have also disrupted a sense of identity in the French Caribbean, especially when considered alongside Chamoiseau's critique of French language.

The structure of the novel and the way in which the narratives and relationships of different characters are interwoven echoes the interdependent ecosystems that can be found in nature. Chamoiseau points

\footnotetext{
${ }^{14}$ For more information about the scandal and its effects see: John Lichfield's 'Health disaster' and Didier Torny's 'Managing an everlastingly polluted world'.

15 This can be seen in Le Code noir (2006 [1685]) in articles 18-20, in which the rights and responsibilities of slaves regarding the selling of produce at markets are set out.
} 
to this in a recent interview, and highlights the links between what he terms as the biosphere and human relations:

La biosphère est un ensemble de relations subtiles, d'équilibres mouvants, imprévisibles, avec des degrés d'alchimie qui dépassent notre entendement. Transposez cela sur les relations entre les cultures, les civilisations, et surtout sur les alchimies entre les individus qui sont aujourd'hui les trajectoires les plus déterminantes, vous toucherez alors au champ de conscience le plus pertinent (Chamoiseau and De Vriese 130)

Chamoiseau seems to transpose the notions of a biosphere onto his narratives and the relationships between the characters in order to show the links he perceives between nature and humanity. Viewing his multiple narratives in Chronique as a biosphere shows the connection between the ever-changing ecosystems of the natural world which incorporates everchanging human relations. Moreover, echoing the messages of Antillanité and Créolité regarding fluidity in identity, Chamoiseau points out the everchanging relationships in the environment which mirror those in society: "Nous devons vivre en pleine conscience dans un écosystème relationnel où toutes les cultures du monde, toutes les trajectoires individuelles, toutes les perceptions sont liées entre elles, se nourrissent, s'échangent, s'opposent, se combattent, s'affectent et se désaffectent, et finalement se changent" (Chamoiseau and De Vriese 130). The ever-changing and interdependent relationships between both characters and each other, and characters and the environment can be seen throughout Chronique. Pipi's ever-changing relationship to the land and the market, and the numerous connections that he makes with other characters, are examples of this. Moreover, the way in which the main narrative is interwoven with character biographies, presented separately using parentheses, is suggestive of the complexity of memory which Chamoiseau claims in an appendix is "tout en ruptures de temps, de lieux, de tons et de manières" (Chronique 247). Maeve McCusker argues that "the instability of narrative form can be seen to reflect both the characters' fractured sense of selfhood, and their contemporary social and economic reality" (22), highlighting how the interwoven and fractured connections of nature can mirror those of memory, identity, and day-to-day life.

The overall structure is also typical of Chamoiseau's other novels as there are two chapters in which the first is optimistic (inspiration), and the second evokes despair (expiration). This negative term expiration can also be linked to the consumption of food through imagery of rotting food and the second chapter coincides with a negative change to the islands as a result of the increase in imperialism and dependency. The dependency of Martinique on the metropole is highlighted in the novel through the relationship with the environment, especially food production. The way in which the Second World War in Europe affects food in Martinique is a clear example. The narrator uses animalistic imagery to describe the markets as being the busy centre of food once again following the end of the war: "Les marchés se réveillèrent comme des chiens sous une eau chaude" (Chronique 75). 
However, this is short-lived and soon "les avions et bateaux de France augmentaient. Ils amenaient des caisses de marchandises à bon marché, des pommes et raisins exotiques à nous chavirer le cœur, des produits inconnus et conservés" (133). This description of apples as 'exotic' and a symbol of imperialism is a key feature in Chamoiseau's novels. As Hardwick (Childhood Autobiography) points out, Chamoiseau often uses the image of an apple as the symbol of a mimic-man, ${ }^{16}$ first explored by V.S Naipaul in The Mimic Men. Mimicry has been theorised by Homi K. Bhabha as "one of the most elusive and effective strategies of colonial power and knowledge" (Bhabha 85), that as a deliberate strategy of the British and French civilising missions is a way of creating a "reformed, recognizable other, as a subject of a difference that is almost the same, but not quite"[original emphasis] (Bhabha 86). For Bhabha, as this difference can highlight humanity it undermines a supposed European superiority and can therefore be seen as a tool for upward mobility. Therefore, although the apple can be seen in Chronique as a symbol of French hegemony, it can also be seen to represent the power to mobilise through its consumption. The apple thus shows how nature and humanity have been dominated by the same colonial force, but once the apple is consumed, and therefore a nature/humanity dualism is broken down, it can serve as a tool for upward mobility.

\section{Capitalism and Consumerism}

Chamoiseau links a lack of awareness of history to globalisation, imperialism and the modernisation of the island which can be seen in his descriptions of the changing food sources: "Bientôt, ils quadrillèrent le pays de libres-services, supermarchés hypermarchés, auprès desquels les nôtres faisaient triste figure" (Chronique 133), which leads to the new market vendors preferring "les poulets-frites des fast-food ou les hamburgers des snacks de cinéma" (170). It is significant that the infestation of rats which shortly follows soon becomes a "[s]igne de notre decadence" (210) and science cannot eliminate them (207-209). This shows Chamoiseau's metaphors of modernisation as an infestation and as those who have enforced modernisation as vermin and provides a link between humanity and nature. In Manifeste pour les 'produits' de baute nécessité, written against the backdrop of the 2009 strikes, Chamoiseau and other authors discuss a challenge to consumerism and capitalism which they claim are exploiting the islands. The authors suggest that as a result "il y a donc une haute nécessité [. . .] de notre autosuffisance énergétique et alimentaire" (Breleur et al. 5). This sentiment is seen in the novel through Pipi's garden and his success as the markets are briefly restored before interference from 'Western' agricultural methods cause its decline. The dangers of capitalism can also be seen in Pipi's death at the end of the novel. Gosson argues that "Chamoiseau, like Glissant before him, warns Martinicans against the

\footnotetext{
${ }^{16}$ For example, in his novel Chemin d'école.
} 
dangers of appropriating the capitalist values of French culture instead of preserving the land as a receptacle of cultural past" ('For What the Land Tells' 224). Gosson points out that Pipi's death "indicates that eventual infection of foreign values which invade even the most resistant of minds" ('For What the Land Tells' 223). This can be seen in the way in which Pipi's father, the dorlis Anatole-Anatole, predicts Pipi's future early in the novel: "Tu sauras parler à la jarre, mais la Belle te mangera..." (Chronique 53). Knepper argues that Pipi's demise is a result of him "[engaging] in a regressive and deluded quest for instant wealth" rather than using his new knowledge of the past to confront present challenges (73). The dorlis' prediction, therefore, could indicate a message from Chamoiseau to his Antillean readers that you can learn about your history, and domination, but consumerism will 'eat you up' if nothing is done to challenge or change it.

Applying the Hegelian master-slave dialectic to the way in which nature has been constructed and dominated both physically and metaphorically in the (post)colonial world shows the links between identity and nature, as the master (human) cannot realise fully their identity without realising the consciousness of the Other (nature). The dialectic can be interpreted in that all forms of consciousness are inextricably interwoven, and the master cannot realise self-consciousness without identifying with the Other and realising the latter's own consciousness. Protagonist Pipi's diminishing respect for the consciousness of the earth, which Chamoiseau seems to attribute to post-colonial consumerism and a lack of collective memory, leads to his deterioration. In the end, Pipi could not be free as he did not fully recognise the potential of nature after his own consciousness had been altered by colonial intervention. Adding another layer of nature's consciousness to the narrative, master storyteller Afoukal warns Pipi of this from his position within the land, providing a metaphor for the memory of slavery and linking nature and humanity.

The linking of nature and humanity is clear throughout Chronique. The deterioration of characters such as Pipi and the djobbers is directly linked to the changing environment as a result of continued imperialism in Martinique. This can be read as a direct critique of colonialism and globalisation, and as a warning of what could happen if it continues, which could be seen in 2009 during the strikes across the French Caribbean. Highlighting the importance and urgency of the debate around food production and the environment in Martinique and Guadeloupe, the 2009 strikes were an example of an attempt to redefine the relationship between the islands and the métropole, thus an attempt to define an identity in relation to power. The strikes began as a protest against raising petrol prices, but soon developed to include the cost of basic necessities such as food (Bonilla 129). Bonilla points out that "the general strike took hold of the public imagination and transformed quotidian life" and Guadeloupeans used local markets and their own gardens for food (126). This approach can be seen in 
the reaction Pipi takes to resist French imperialism in the novel by creating a Creole garden for self-sufficiency after learning about the history of the islands and the role of the garden during slavery. The idea of this selfsufficiency is also hinted at in Lettre ouverte as Ernest Pépin suggests breaking away from "[] a sacro-sainte consummation" (6), a situation that he attributes mainly to the young people of Martinique. Bonilla also argues that the strikes enabled the islands to both imagine and experience "economic, social and political configurations [...] by providing a break from the nexus of quotidian life" (127), a sentiment echoed by the reaction of the community to Pipi's garden.

\section{Conclusion}

The analysis of important literary scenes in which the link between the environment and identity is foregrounded highlights the urgency of addressing the Francophone Caribbean relationship between humanity and nature for the revelations it holds regarding both identity and economic issues. The way in which food in particular is sourced in Martinique and Guadeloupe emerges as an increasingly urgent theme, as underscored by the 2009 strikes. By working through a series of crucial moments that reveal the tensions between the representation of the environment and identity in Francophone Caribbean literature, it emerges that the representation of the environment uncovers an urgent need for a discussion concerning conservation and food production in the region in a way that moves beyond a nature/human dualism.

A key question arising from this work is how to progress beyond the master/slave relationship that has been constructed between humans and nature. This needs to be considered alongside the relationships constructed within humanity in the region through the use of slavery, and the continued estrangement forged between Antilleans and the land. Furthermore, problems that have emerged in the region (as well as world-wide) as a result of capitalism and globalisation need to be addressed in order to limit the devastating effects that humans are having on the Earth as a result of a continued nature/culture dualism. Chamoiseau's suggestion of viewing the natural environment, as well as identities, as a series of ecosystems which need to be respected and protected in their own right provides a starting point to address this urgent question facing all living beings. 


\section{Bibliography}

Aldrich, Robert and John Connell. France's Overseas Frontier: Départements et Territoires d'Outre-mer. Cambridge University Press, 1992.

Benítez-Rojo, Antonio. The Repeating Island. Translated by James Maraniss. Duke University Press, 1996.

Bernabé, Jean, Patrick Chamoiseau, and Raphaël Confiant. 'In Praise of Creoleness'. Translated by Mohamed B. Taleb Khyar. Callaloo, vol. 13, ${ }^{\circ}$ 4, 1990. pp. 886-909.

---. Éloge de la Créolité. Gallimard 1989.

Bhabha, Homi K. The Location of Culture. Routledge, 1994.

Bishop, Matthew and Anthony Payne. 'Climate Change and the Future of Caribbean Development.' Journal of Development Studies, vol. 48, n¹0, 2012, pp. 1536-1553.

Bojsen, Heidi. 'Flashbacks of an Orchid.' Caribbean Literature and the Environment, edited by Elizabeth M. DeLoughrey, Renée K. Gosson, and George B. Handley, University of Virginia Press, 2005, pp. 213-225.

Bonilla, Yarimar. 'GUADELOUPE IS OURS.' Interventions, vol. 12, $\mathrm{n}^{\circ} 1$, 2010, pp. 125-137.

Breleur, Ernest, et al. Manifeste pour les "produits" de haute nécessité. Galaade Éditions, 2009.

Césaire, Aimé. Cabier d'un retour au pays natal. Présence Africaine, 1956.

Chamoiseau, Patrick. Chronique des sept misères. Gallimard, 1986.

---. Chemin-d'école. Gallimard, 1996

---. Chronicle of the Seven Sorrows. Translated by Linda Coverdale, University of Nebraska Press, 1999.

---. 'Frères migrants.' Seuil, 2017, www.approches.fr/Declaration-des-poetesFreres. Accessed 17 Dec. 2017.

Chamoiseau, Patrick and Hannes De Vriese. 'L'écriture de la nature ou le texte vivant.' Revue critique de fixxion française contemporaine, no. 11, 2015, pp. 128-132, www.revue-critique-de-fixxion-francaisecontemporaine.org/rcffc/article/view/fx11.14/998. Accessed 10 August 2016.

Chamoiseau, Patrick, et al. 'Manifeste pour refonder les DOM', 2000, www.jacbayle.perso.neuf.fr/livres/manifeste.html. Accessed 7 August 2016.

Dash, J. Michael. The other America: Caribbean Literature in a New World Context. University Press of Virginia, 1998.

Deleuze, Gilles and Félix Guattari. Mille Plateaux. 1980. Editions de Minuit, 1998.

DeLoughrey, Elizabeth M., Renée K. Gosson and George B. Handley, editors. Caribbean Literature and the Environment: between Nature and Culture. University of Virginia Press, 2005.

DeLoughrey, Elizabeth M. and George B. Handley. Postcolonial Ecologies: Literature of the Environment. Oxford University Press, 2011. 
Descartes, René. Discourse on method; and the Meditations. Translated by F.E. Sutcliffe, Penguin Books, 1968.

Finch-Race. A. and Stephanie Posthumus, editors. French ecocriticism: from the early modern period to the twenty-first century. Peter Laing, 2017.

Glissant, Édouard. Caribbean Discourse: Selected Essays. Translated by J. Michael Dash, University Press of Virginia, 1989.

---. Le Discours antillais. Seuil, 1981.

---. Poétique de la Relation (Poétique III). Gallimard, 1990.

Gorz, André/Bosquet, Michel. Ecologie et politique. 1975. Editions du Seuil, 1978.

Gosson, Renée K. 'For What the Land Tells: An Ecocritical Approach to Patrick Chamoiseau's "Chronicle of the Seven Sorrows".' Callaloo, vol. 26, no. 1, 2003, pp. 219-234.

Hardwick, Louise. 'Depicting Social Dispossession in Guadeloupe: Nèg maron, Lettre ouverte à la jeunesse and the General Strike of 2009.' Forum of Modern Languages Studies, vol. 48, n³, 2012, pp. 288-305.

---. Childhood, Autobiography and the Francophone Caribbean. Liverpool University Press, 2013.

---. 'Towards Biopolitical Ecocriticism: the Example of the Manifeste pour les 'produits' de haute nécessité' in French Studies, vol. 70, $\mathrm{n}^{\circ}$ 2, 2016, www.fs.oxfordjournals.org/content/early/2016/06/04/fs.knw127.full. Accessed 8 July 2016.

Hegel, Georg Wilhelm Friedrich. Phenomenology of spirit. Translated by A. V Miller, Clarendon Press, 1977.

Knepper, Wendy. Patrick Chamoiseau: A Critical Introduction. University Press of Mississippi, 2012.

Latour, Bruno. Politics of nature: how to bring the sciences into democracy. Translated by Catherine Porter, Harvard University Press, 2004.

---. Politiques de la nature: comment faire entrer les sciences en démocratie. La Découverte, 1999.

Le Code noir et autres textes de lois sur l'esclavage. 1685. Éditions Sépia, 2006.

Lichfield, John. 'Health disaster' in French Caribbean linked to pesticides', Independent, $18 \quad$ September 2007, www.independent.co.uk/news/world/europe/health-disaster-in-frenchcaribbean-linked-to-pesticides-402816.html. Accessed 10 June 2016.

'Martinique', www.britannica.com/place/Martinique. Accessed 20 October 2017.

McCusker, Maeve. 'Beginnings: The Enigma of Origin.' Patrick Chamoiseau: Recovering Memory. Liverpool University Press, 2007 pp. 21-46.

Milne, Lorna. 'Echanges et ouvertures: le marché.' Patrick Chamoiseau: espaces d'une identité antillaise. Rodopi, 2006.

Naipaul, V.S. The Mimic Men. 1967. Penguin, 1973.

Pagden, Anthony. European encounters with the New World: from Renaissance to Romanticism. Yale University Press, 1993. 
Paravisini-Gebert, Lizabeth. 'Extinctions.' The Oxford Handbook of Ecocriticism, edited by Greg Garrard. Oxford University Press, 2014, pp. 341-357.

---. 'Food, Biodiversity, Extinctions: Caribbean Fauna and the Struggle for Food Security during the Conquest of the New World.' West Indian Literature, vol. 24, n², 2016, pp 11-26.

Pépin, Ernest. 'Lettre Ouverte à la Jeunesse.' Rapport du Conseil Economique et Social, Régional de Martinique, 2010, pp. 5-22.

Plumwood, Val. Environmental culture: the ecological crisis of reason. Routledge, 2002.

Serres, Michel. Le Contrat Naturel. Flammarion, 1992.

Torny, Didier. 'Managing an everlastingly polluted world. Food Policies and community health actions in the French West Indies.' Toxicants, Health and Regulation since 1945, edited by Soraya Boudia and Nathalie Jas, Pickering \& Chatto, 2013, pp. 117-134. www.halshs.archivesouvertes.fr/halshs-01247022. Accessed 9 August 2016.

Walcott, Derek. 'The Sea is History.' Collected Poems 1948-1984. Farrar, Straus \& Giroux, 1986, pp. 364-67.

Watts, Richard. 'Towards an ecocritical postcolonialism: Val Plumwood's Environmental Culture in dialogue with Patrick Chamoiseau.' Journal of Postcolonial Writing, vol. 44, n⿳3, 2008, pp. 251-261, DOI:10.1080/17449850802230285. Accessed 26 September 2017.

Zobel, Joseph. La rue Cases-Nègres. 1950. Présence africaine, 1974. 